\title{
Determination of isoproterenol in pharmaceutical and biological samples using a pyrogallol red multiwalled carbon nanotube paste electrode as a sensor
}

\author{
Mohsen Keyvanfard*, Khadijeh Alizad \\ Department of Chemistry, Majlesi Branch, Islamic Azad University, Isfahan, Iran
}

\section{A R T I C L E I N F O}

Article history:

Received 10 October 2015

Accepted 5 January 2016

Published 5 April 2016

\section{Keywords:}

Isoproterenol

Pharmaceutical analysis

Pyrogallol red

Voltammetry

Multiwalled carbon nanotubes

\begin{abstract}
A B S T R A C T
Isoproterenol (ISPR) is an important catecholamine-based drug that is widely used in the treatment of heart disease. However, overdose of this drug is very dangerous to the human body. In this study, a new sensor based on a pyrogallol red modified-multiwalled carbon nanotube paste electrode (PGRMMWCNTPE) was prepared and used for high sensitivity determination of ISPR in aqueous solution. Electrocatalytic oxidation of ISPR at the PGRMMWCNTPE was investigated by chronoamperometry, cyclic voltammetry, and square-wave voltammetry. The values of the catalytic rate constant, electron transfer coefficient, and diffusion coefficient for ISPR oxidation were then calculated using voltammetric data. A linear calibration curve was constructed for ISPR concentration in the range $0.8-570 \mu \mathrm{mol} / \mathrm{L}$ with a detection limit of $0.47 \mu \mathrm{mol} / \mathrm{L}$ ISPR. The sensor was then applied to the determination of ISPR in urine and drug samples with satisfactory results.
\end{abstract}

(C) 2016, Dalian Institute of Chemical Physics, Chinese Academy of Sciences. Published by Elsevier B.V. All rights reserved.

\section{Introduction}

Isoproterenol (ISPR, isoprenaline) is a catecholamine-based drug that is widely used in asthmatic therapy, allergic emergencies, bronchial asthma, ventricular bradycardia, cardiac arrest, glaucoma, and as a styptic. ISPR under the brand name Isuprel in ampoule form is used to treat asthma, chronic bronchitis, and emphysema [1]. The cardiovascular effects of ISPR are similar to those of adrenaline and noradrenaline, which can relax almost any type of smooth muscle that contains adrenergic nerves. Adjusting the dose of medications by rapid determination of their concentration in biological fluids is very important. Hence, accurately determining their concentration is important. Analysis of catecholamine drugs in biological fluids, where they are found at relatively low concentrations, generally requires the use of selective and highly sensitive techniques with high detectability, such as high performance liquid chro- matography with fluorometric [2] and/or with electrochemical $[3,4]$ detection. Voltammetric systems for detecting drug and biological samples are cheap and sensitive techniques because they are widely used to analyze electroactive materials [5-10]. Electrochemical-based methods are fast, sensitive, selective, and simple methods for determining important electroactive materials in pharmaceutical and biological samples [11-20].

Modifying electrode substrates with nanomaterials such as graphene, metal oxide nanoparticles, metal-based nanoparticles, and carbon nanotubes (CNTs) for use in analytical sensing has been reported to result in low detection limits, a high linear dynamic range, high sensitivity, good selectivity, and the reduction of overpotentials [21-30]. CNTs are a class of nanomaterials that have a wide range of applications [31-35].

In this study, the suitability of a pyrogallol red modifiedmultiwalled carbon nanotube paste electrode (PGRMMWCNTPE) for the electrocatalytic determination of ISPR was investigated

* Corresponding author. E-mail: keyvan45638@yahoo.com 
using cyclic voltammetry (CV) and square-wave voltammetry (SWV). The effect of different parameters, such as electrode composition, electrolyte, $\mathrm{pH}$, potential scan rate, and interference on the potential was investigated by CV. The proposed sensor was then used to determine the concentration of ISPR in pharmaceutical and biological samples.

\section{Experimental}

For all of the electrochemical investigation, we used a potentiostat/galvanostat (Autolab PGSTAT 302N, the Netherlands) connected to a three-electrode cell (663 VA Stand, Metrohm, Herisau, Switzerland) linked to a computer (Pentium IV, $1200 \mathrm{MHz}$ ) with Autolab software. A platinum wire was used as the auxiliary electrode. The PGRMMWCNTPE and a $\mathrm{Ag} / \mathrm{AgCl} / \mathrm{KCl}_{\text {sat }}$ electrode were used as the working and reference electrodes, respectively. The electrode prepared with CNTs was characterized by scanning electron microscopy (SEM, AIS 2100, Seron Technologies).

\section{Results and discussion}

\subsection{SEM characterization}

Figure 1 shows the typical morphologies of the carbon paste electrode (CPE) and the PGRMMWCNTPE characterized by SEM. As shown in Fig. 1(b), the mediator (pyrogallol red, PGR) is distributed on the surface of the modified electrode and the morphology of the modified electrode remains unchanged. This indicates that PGR and multiwall CNTs (MWCNTs) almost homogeneously distribute on the surface of the carbon paste matrix, which exhibits a unique three-dimensional structure.

\subsection{Electrochemical investigation}

The electrochemical behavior of the modified electrode was investigated by $\mathrm{CV}$ in phosphate buffer solution (PBS, pH 7.0). The experimental results show well-defined and reproducible anodic and cathodic peaks related to the $\mathrm{PGR}_{(\mathrm{Red})} / \mathrm{PGR}_{(0 \mathrm{x})}$ redox couple with quasi-reversible behavior and peak separation of $\Delta E_{\mathrm{p}}=E_{\mathrm{pa}}-E_{\mathrm{pc}}=180 \mathrm{mV}$. These cyclic voltammograms were used to determine the relationship between the anodic peak current $\left(I_{\mathrm{pa}}\right)$ and the square root of the potential scan rate $\left(v^{1 / 2}\right)$ (Fig. 2). From Fig. 2, $I_{\mathrm{pa}}$ is linearly dependent on $v^{1 / 2}$ with a correlation coefficient of $R^{2}=0.9996$. This indicates that the redox system shows Nernstian behavior.

One important objective of the present study was to develop a modified sensor capable of electrocatalytic oxidation of ISPR. We obtained the cyclic voltammetric responses for the electro-

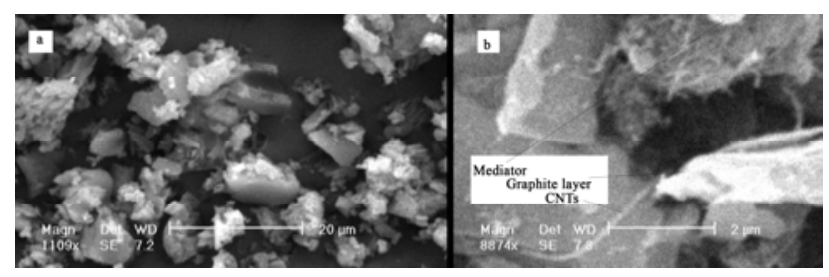

Fig. 1. SEM images of (a) the CPE and (b) the PGRMMWCNTPE.

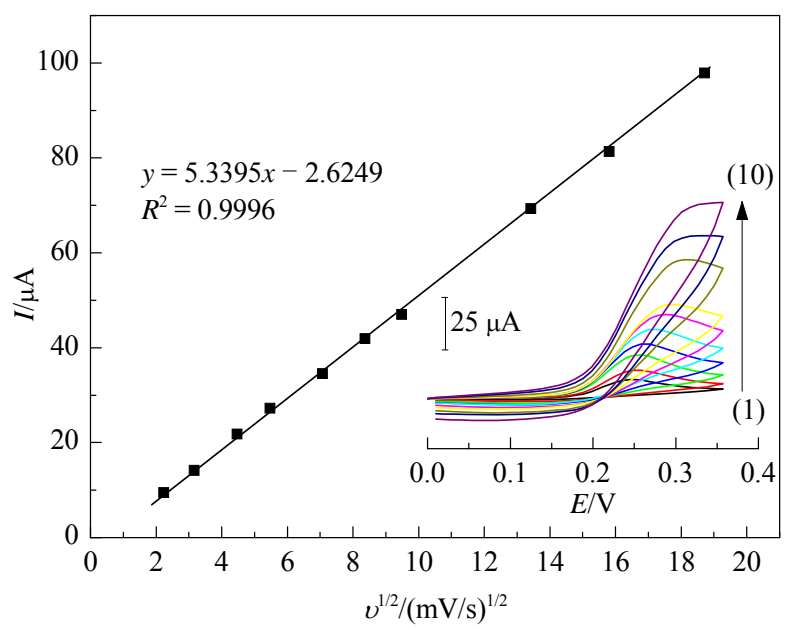

Fig. 2. Plot of $I_{\mathrm{pa}}$ versus $v^{1 / 2}$ for the oxidation of ISPR by the PGRMMWCNTPE. The inset shows cyclic voltammograms for various scan rates of 5 (1), 10 (2), 20 (3), 30 (4), 50 (5), 70 (6), 90 (7), 180 (8), 250 (9), and $350 \mathrm{mV} / \mathrm{s} \mathrm{(10)} \mathrm{in} 0.1 \mathrm{~mol} / \mathrm{L}$ PBS (pH 7.0).

chemical oxidation of $500 \mu \mathrm{mol} / \mathrm{L}$ ISPR at the PGRMMWCNTPE (Fig. 3) and at the PRG-modified CPE (PGRCPE). In Fig. 3, curves (4) and (5) are the same as curves (3) and (2) but without the mediator.

These results show that the sensor produces a large anodic peak current in the presence of ISPR without a cathodic counterpart (Fig. 3, curves (3) and (2)). Curve (1) shows the cyclic voltammogram of the PGRMMWCNTPE in PBS ( $\mathrm{pH}$ 7.0). The current observed is associated with ISPR oxidation and not oxidation of the modifier, which was determined by comparing the current in the presence and absence of ISPR. At the surface of the MWCNT paste electrode (MWCNTPE) and the CPE without mediator, ISPR was oxidized at around $357 \mathrm{mV}$. The electroactivity of ISPR on the PGRMMWCNTPE and the PGRCPE was significant (Fig. 3) with a strongly defined peak potential at around $277 \mathrm{mV}$ (vs. $\mathrm{Ag} / \mathrm{AgCl} / \mathrm{KCl}_{\text {sat) }}$. Thus, a decrease in the overpotential and enhancement of the peak current for ISPR oxidation were achieved with the PGRMMWCNTPE and the

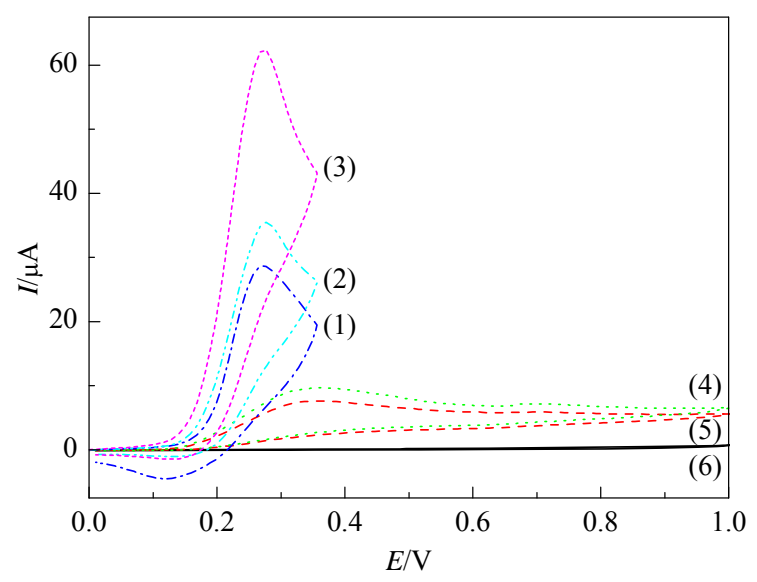

Fig. 3. Cyclic voltammograms of PBS at the PGRMMWCNTPE (1), 500 $\mu \mathrm{mol} / \mathrm{L}$ ISPR at the PGRCPE (2), PGRMMWCNTPE (3), CNPE (4), and CPE (5), and PBS at the CNPE (6). Conditions: $0.1 \mathrm{~mol} / \mathrm{L}$ PBS (pH 7.0) and scan rate $20 \mathrm{mV} / \mathrm{s}$. 
<smiles>Oc1ccc(C2c3cccc(O)c3Oc3c2ccc(O)c3O)c(O)c1O</smiles>

Electrochemical reaction

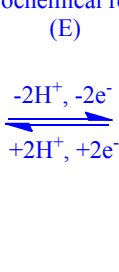<smiles>[R6]c1cccc(-c2c3ccc(=O)c(O)c-3oc3c2C=CC(=O)C3=O)c1[R](=O)O</smiles><smiles>CC(C)NCC(O)c1ccc(O)c(O)c1</smiles>

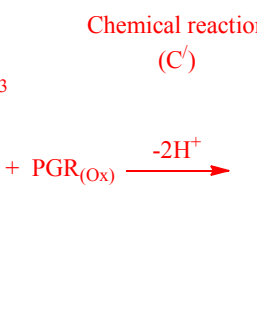

Scheme 1. Electrocatalytic mechanism for determining ISPR at the surface of the PGRMMWCNTPE.

\section{PGRCPE}

When we compared the oxidation of ISPR at the surfaces of the PGRMMWCNTPE and the PGRCPE, a dramatic enhancement of the anodic peak current occurred at the PGRMMWCNTPE compared with the value obtained with the PGRCPE. In other words, the data clearly show that the combination of the MWCNTPE and the mediator definitely improves the characteristics of the electrode for the oxidation of ISPR. The process corresponds to an $\mathrm{EC}^{\prime}$ (catalytic) mechanism (Scheme 1), where the electrochemically formed PGR $_{(0 x)}$ chemically reacts with ISPR that diffused toward the electrode surface, while the simultaneous oxidation of the regenerated $\mathrm{PGR}_{(\mathrm{Red})}$ causes an increase in the anodic current. For the same reason, the cathodic current of the modified electrode is smaller in the presence of ISPR.

In the scan rate investigation, the peak current for ISPR oxidation at the surface of the PGRMMWCNTPE was proportional

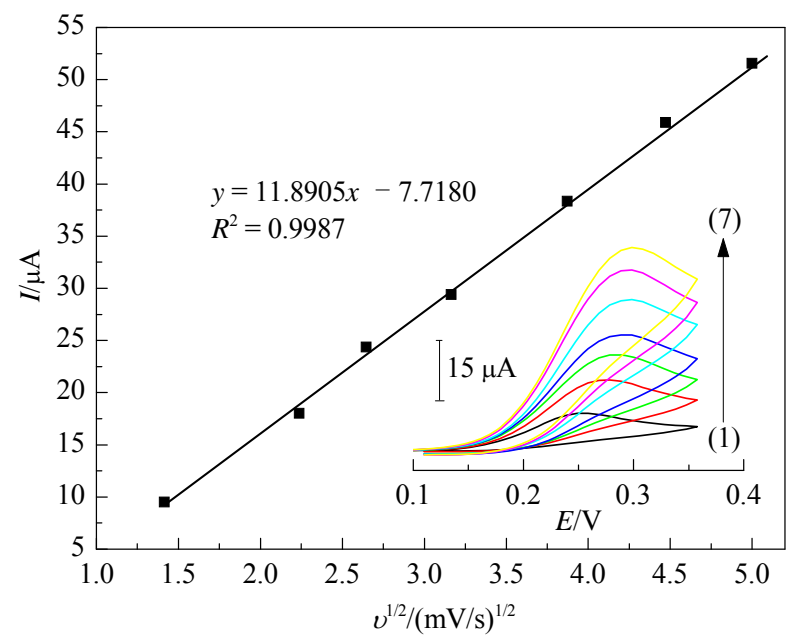

Fig. 4. Plot of $I_{\text {pa }}$ versus $v^{1 / 2}$ for the oxidation of $300 \mu \mathrm{mol} / \mathrm{L}$ ISPR at the surface of the PGRMMWCNTPE. The inset shows cyclic voltammograms of $300 \mu \mathrm{mol} / \mathrm{L}$ ISPR at the PGRMMWCNTPE for various scan rates of 2 (1), 5 (2), 7 (3), 10 (4), 15 (5), 20 (6), and $25 \mathrm{mV} / \mathrm{s}$ (7) in $0.1 \mathrm{~mol} / \mathrm{L} \mathrm{PBS}$ (pH 7.0).

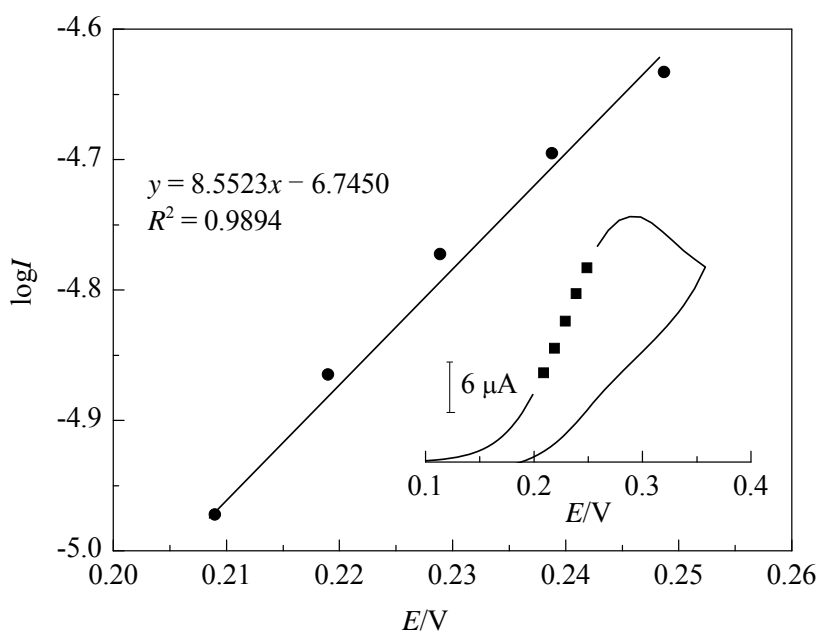

Fig. 5. Tafel plot for the PGRMMWCNTPE in $0.1 \mathrm{~mol} / \mathrm{L}$ PBS (pH 7.0) with a scan rate of $10 \mathrm{mV} / \mathrm{s}$ in the presence of $300 \mu \mathrm{mol} / \mathrm{L}$ ISPR. The inset shows the cyclic voltammograms (at $10 \mathrm{mV} / \mathrm{s}$ ) obtained with the PGRMMWCNTPE in $0.1 \mathrm{~mol} / \mathrm{L}$ PBS (pH 7.0).

to the square root of the scan rate $\left(v^{1 / 2}\right)$ (Fig. 4). This result clearly indicates a diffusion-controlled electro-oxidative process.

To obtain information about the rate-determining step, a Tafel plot was constructed for ISPR oxidation at the PGRMMWCNTPE using the data derived from the increasing part of the current-voltage curve (Fig. 5). The slope of the Tafel plot is $n(1-\alpha) F / 2.3 R T$, which is equal to $8.5523 \mathrm{~V}^{-1}$ decade. This gives $n \alpha=0.49$. Assuming that $n=1$ then $\alpha=0.49$.

Double potential step chronoamperometry was used with the PGRMMWCNTPE to determine the diffusion coefficient of ISPR in aqueous solution. According to the Cottrell equation, we calculated a diffusion coefficient of $D=8.73 \times 10^{-5} \mathrm{~cm}^{2} / \mathrm{s}$ for ISPR.

We also determined the catalytic reaction rate constant $k \mathrm{~h}$ for ISPR using the Galus method. Based on the slope of the $I_{\mathrm{C}} / I_{\mathrm{L}}$ ( $I_{\mathrm{C}}$ is the catalytic current and $I_{\mathrm{L}}$ is the limited current in the absence of ISPR) versus $t^{1 / 2}$ plot, $k_{\mathrm{h}}$ can be obtained for a given ISPR concentration. From the values of the slopes, the average value of $k_{\mathrm{h}}$ was found to be $k_{\mathrm{h}}=8.42 \times 10^{3} \mathrm{~mol}^{-1} \mathrm{~L} \mathrm{~s}^{-1}$.

SWV was used for determining ISPR (Fig. 6, inset). There is a linear relationship between the peak current $\left(I_{\mathrm{p}}\right)$ and the ISPR concentration $\left(C_{\mathrm{ISPR}}\right)$ in the range $0.8-570 \mu \mathrm{mol} / \mathrm{L}$ ISPR with the regression equation of $I_{\mathrm{p}}(\mu \mathrm{A})=(0.0255 \pm 0.0011) C_{\mathrm{ISPR}}+$ (22.5281 \pm 0.4122$)\left(R^{2}=0.9962, n=10\right)$ (Fig. 6).

The detection limit was determined to be $0.47 \mu \mathrm{mol} / \mathrm{L}$ ISPR according to the definition of the limit of detection (LOD) = $3 s_{\mathrm{b}} / m$, where $s_{\mathrm{b}}$ is the standard deviation of the blank signal $(n$ $=10$ ) and $m$ is the slope of the calibration.

\subsection{Interference study and real sample analysis}

The influence of various substances on determination of ISPR was investigated with $5.0 \mu \mathrm{mol} / \mathrm{L}$ ISPR. We found that only $250 \mu \mathrm{mol} / \mathrm{L}$ thiourea and $5.0 \mu \mathrm{mol} / \mathrm{L}$ ascorbic acid interfere with the determination of ISPR. Although ascorbic acid shows interference, interference from ascorbic acid can be 


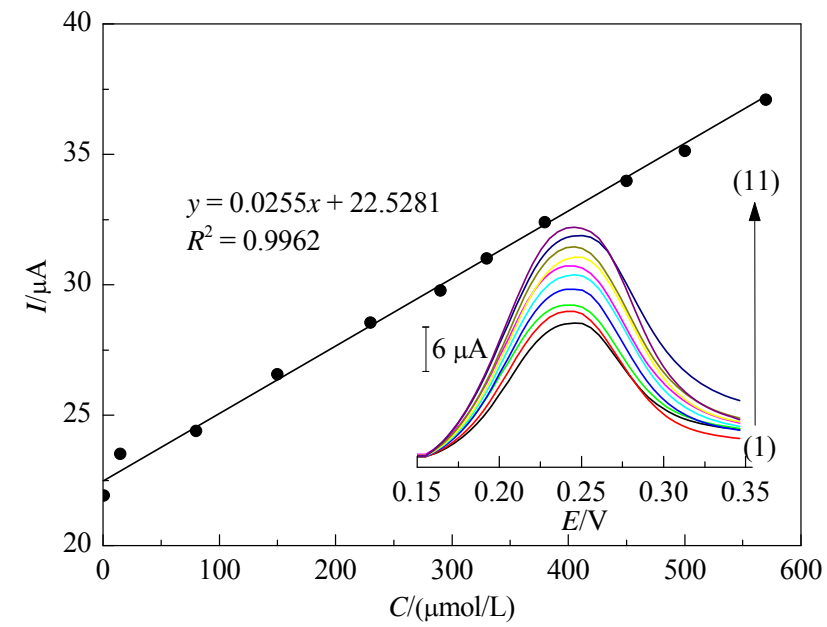

Fig. 6. Plot of the electrocatalytic peak current as a function of ISPR concentration. The inset shows square-wave voltammograms of the PGRMMWCNTPE in $0.1 \mathrm{~mol} / \mathrm{L}$ PBS (pH 7.0) containing different concentrations of ISPR, from (1) to (11), 0.8, 15, 80, 150, 230, 290, 330, 380 450,500 , and $570.0 \mu \mathrm{mol} / \mathrm{L}$ ISPR.

minimized by using an ascorbic oxidase enzyme, which shows high selectivity for oxidation of ascorbic acid. We found that other compounds, such as glucose, fructose, lactose, sucrose, glycine, and methionine, do not significantly interfere with determination of ISPR at a surface of the modified electrode. Additionally, saturated starch solution and $2 \mathrm{mmol} / \mathrm{L}$ uric acid did not interfere with the determination of ISPR.

To evaluate the electroanalytical applicability of the proposed sensor, it was applied to the determination of ISPR in urine and ampoule samples. The results for determination of ISPR in the real samples are given in Table 1.

The results obtained for the real samples using the proposed method were statistically compared with the published results for another electrochemical sensor [36] using the Student's $t$ test (for accuracy) and the variance ratio $F$ test (for precision) at the $95 \%$ confidence level. Clearly, the modified electrode is capable of voltammetric determination of ISPR with high selectivity and good reproducibility.

\section{Conclusions}

We report a carbon paste electrode chemically modified with PGR and MWCNTs as a modifier for determining ISPR in aqueous solution. This sensor is simple to prepare and surface renewal is easy. The electrochemical behavior of the mediator was investigated by $\mathrm{CV}$ and chronoamperometry in both the absence and presence of ISPR at pH 7.0, which is the optimum
$\mathrm{pH}$ for analysis. The catalytic peak current obtained by SWV is linearly dependent on the ISPR concentration with a minimum ISPR concentration of $0.80 \mu \mathrm{mol} / \mathrm{L}$. The current sensitivity, low detection limit, and high selectivity of the PGRMMWCNTPE indicate that the sensor shows potential for the determining ISPR in pharmaceutical and biological samples.

\section{Acknowledgments}

The authors wish to thank Majlesi Branch, Islamic Azad University, for their support.

\section{References}

[1] L. Goodman, A. Gilman, The Pharmacological Basis of Therapeutics, 9 ed., McGraw-Hill Professional, New York, 1996, 105.

[2] L. Elrod, J. L. Schmit, J. A. Morley, J. Chromatogr. A, 1996, 723, 235-241.

[3] B. J. Sanghavi, S. M. Mobin, P. Mathur, G. K. Lahiri, A. K. Srivastava, Biosens. Bioelectron., 2013, 39, 124-132

[4] A. A. Ensafi, H. K. Maleh, Int. J. Electrochem. Sci., 2010, 5, 1484-1495.

[5] H. Karimi-Maleh, F. Tahernejad-Javazmi, A. A. Ensafi, R. Moradi, S. Mallakpour, H. Beitollahi, Biosens. Bioelect., 2014, 60, 1-7.

[6] M. Keyvanfard, H. Karimi-Maleh, K. Alizad, Chin. J. Catal., 2013, 34, 1883-1889.

[7] M. Keyvanfard, M. Ahmadi, F. Karimi, K. Alizad, Chin. Chem. Lett., 2014, 25, 1244-1246.

[8] A. S. Isfahani, M. Keyvanfard, B. Rezaei, K. Alizad, Current Nanosci., 2014, 10, 512-520.

[9] J. Barek, J. Fischer, J. C. Moreira, J. Wang, in: K. Kalcher, R. Metelka, I. Švancara, K. Vytřas eds., Sensing in Electroanalysis, University Press Centre, Pardubice, 2013/2014, Volume 8.

[10] A. A. Ensafi, E. Khoddami, H. Karimi-Maleh, Int. J. Electrochem. Sci., 2011, 6, 2596-2608.

[11] B. J. Sanghavi, W. Varhue, J. L. Chávez, C. F. Chou, N. S. Swami, Anal. Chem., 2014, 86, 4120-4125.

[12] S. N. Azizi, S. Ghasemi, N. S. Gilani, Chin. J. Catal., 2014, 35, 383-390.

[13] A. A. Ensafi, M. Lotfi, H. Karimi-Maleh, Chin. J. Catal., 2012, 33, 487-493.

[14] B. Habibi, M. Abazari, M. H. Pournaghi-Azar, Chin. J. Catal., 2012, 33, 1783-1790.

[15] H. Karimi-Maleh, F. Tahernejad-Javazmi, N. Atar, M. L. Yola, V. K. Gupta, A. A. Ensafi, Ind. Eng. Chem. Res., 2015, 54, 3634-3639.

[16] M. R. Ganjali, P. Norouzi, M. Ghorbani, A. Sepehri, Talanta, 2005, 66, 1225-1233.

[17] P. Norouzi, M. R. Ganjali, M. Zare, A. Mohammadi, J. Pharm. Sci,, 2007, 96, 2009-2017.

[18] P. Norouzi, M. R. Ganjali, T. Alizadeh, P. Daneshgar, Electroanalysis, 2006, 18, 947-954.

Table 1

Determination of isoproterenol in real samples using the proposed sensor and the results of a previously published method.

\begin{tabular}{|c|c|c|c|c|c|c|c|c|}
\hline Sample & Added $(\mu \mathrm{mol} / \mathrm{L})$ & Expected $(\mu \mathrm{mol} / \mathrm{L})$ & Detected $(\mu \mathrm{mol} / \mathrm{L})$ & Published method $(\mu \mathrm{mol} / \mathrm{L})$ & $F_{\mathrm{ex}}$ & $F_{\text {tab }}$ & $t_{\mathrm{ex}}$ & $t_{\text {tab }}$ \\
\hline \multirow[t]{4}{*}{ Urine } & - & $<\mathrm{LOD}$ & $<\mathrm{LOD}$ & - & - & - & - & - \\
\hline & 5.00 & 5.00 & $5.20 \pm 0.02$ & $5.36 \pm 0.42$ & 8.6 & 19.0 & 2.1 & 3.8 \\
\hline & 10.00 & 15.00 & $14.81 \pm 0.68$ & $15.35 \pm 0.54$ & - & - & - & - \\
\hline & 15.00 & 20.00 & $20.30 \pm 0.05$ & $20.30 \pm 0.05$ & - & - & - & - \\
\hline \multirow[t]{2}{*}{ Ampoule } & - & Unknown & $4.70 \pm 0.24$ & $5.11 \pm 0.35$ & - & - & - & - \\
\hline & 5.30 & 10.00 & $10.30 \pm 0.16$ & $10.35 \pm 0.41$ & 8.1 & 19.0 & 1.9 & 3.8 \\
\hline
\end{tabular}




\title{
Graphical Abstract
}

Chin. J. Catal., 2016, 37: 579-583 doi: 10.1016/S1872-2067(15)61036-1

\section{Determination of isoproterenol in pharmaceutical and biological samples using a pyrogallol red multiwalled carbon nanotube paste electrode as a sensor}

Mohsen Keyvanfard*, Khadijeh Alizad

Islamic Azad University, Iran

The carbon past electrode modified with carbon nanotubes was used as a highly sensitive sensor for determination of isoproterenol using pyrogallol red as a mediator.
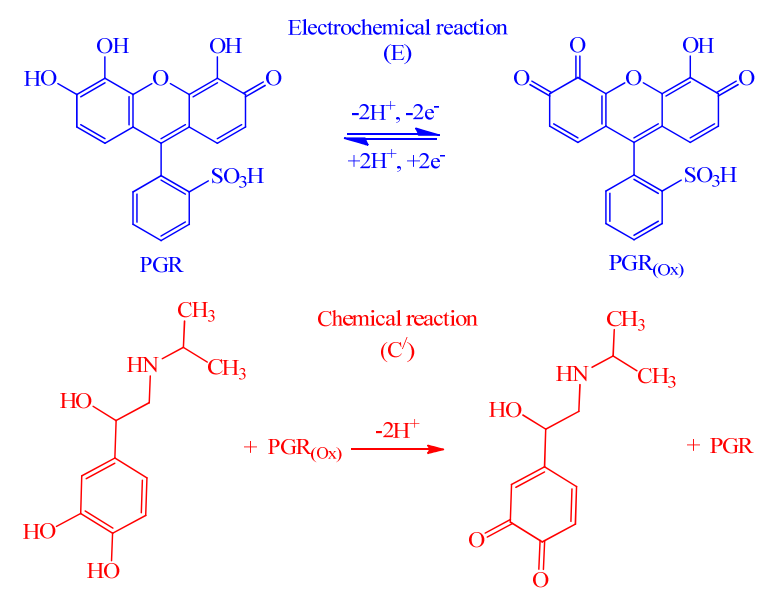

[19] P. Norouzi, M. R. Ganjali, L. Hajiaghababaei, Anal. Lett., 2006, 39 , 1941-1953.

[20] T. Alizadeh, M. R. Ganjali, M. Zare, P. Norouzi, Electrochim. Acta, 2010, 55, 1568-1574.

[21] B. J. Sanghavi, A. K. Srivastava, Electrochim. Acta, 2010, 55 8638-8648.

[22] M. L. Yola, N. Atar, Electrochim. Acta, 2014, 119, 24-31.

[23] B. J. Sanghavi, A. K. Srivastava, Electrochim. Acta, 2011, 56, 4188-4196.

[24] B. J. Sanghavi, P. K. Kalambate, S. P. Karna, A. K. Srivastava, Talanta, 2014, 120, 1-9

[25] M. L. Yola, N. Atar, Z. Üstündağ, A. O. Solak, J. Electroanal. Chem., 2013, 698, 9-16.

[26] M. L. Yola, T. Eren, N. Atar, Sens. Actuators B, 2014, 195, 28-35.

[27] H. Karimi-Maleh, P. Biparva, M. Hatami, Biosens. Bioelect., 2013, $48,270-275$.

[28] R. Sadeghi, H. Karimi-Maleh, A. Bahari, M. Taghavi, Phys. Chem.
Liq., 2013, 51, 704-714.

[29] R. Moradi, S. A. Sebt, H. Karimi-Maleh, R. Sadeghi, F. Karimi, A. Bahari, H. Arabi, Phys. Chem. Chem. Phys., 2013, 15, 5888-5897.

[30] M. Najafi, M. A. Khalilzadeh, H. Karimi-Maleh, Food Chem., 2014, 158, 125-131.

[31] M. Keyvanfard, V. Khosravi, H. Karimi-Maleh, K. Alizad, B. Rezaei, J. Mol. Liq., 2013, 177, 182-189.

[32] M. Elysi, M. A. Khalilzadeh, H. Karimi-Maleh, Food Chem., 2013, 141, 4311-4317.

[33] M. Keyvanfard, R. Salmani-Mobarakeh, H. Karimi-Maleh, K. Alizad, Chin. J. Catal., 2014, 35, 1166-1172.

[34] A. A. Ensafi, H. Karimi-Maleh, J. Electroanal. Chem., 2010, 640, 75-83

[35] E. M. Silva, R. M. Takeuchi, A. L. Santos, Food Chem., 2015, 173, 763-769.

[36] H. Karimi-Maleh, S. Rostami, V. K. Gupta, M. Fouladgar, J. Mol. Liq., 2015, 201, 102-107.

\section{邻苯三酚红多壁碳纳米管糊电极为传感器分析制药和生物样品中异丙基肾上腺素}

\author{
Mohsen Keyvanfard ${ }^{*}$, Khadijeh Alizad \\ 伊斯兰自由大学马杰斯分校化学系, 伊斯法罕, 伊朗
}

摘要: 异丙基肾上腺素(ISPR)是一种重要的邻苯二酚胺类药物, 广泛用于治疗心脏疾病. 然而, 过量服用该药对人体非常 危险. 本文采用邻苯三酚红修饰多壁碳纳米管糊电极(PGRMMWCNTPE)制备了一种新型传感器, 用于高灵敏度检测水溶 液中的ISPR. 采用计时电流法、循环伏安法和方波伏安法考察了PGRMMWCNTPE电极电催化氧化ISPR性能. 通过伏安数 据计算了ISPR氧化的催化反应速率常数、电子传递系数和扩散系数. 在ISPR浓度 $0.8-570 \mu \mathrm{mol} / \mathrm{L}$ 范围内建立了线性标准曲 线, 检测限为 $0.47 \mu \mathrm{mol} / \mathrm{L}$ ISPR. 将该传感器用于尿液和药物样品中ISPR检测得到满意结果.

关键词: 异丙基肾上腺素; 药物分析; 邻苯三酚红; 伏安法; 多壁碳纳米管

收稿日期: 2015-10-10. 接受日期: 2016-01-05. 出版日期: 2016-04-05.

*通讯联系人. 电子信箱: keyvan45638@yahoo.com

本文的英文电子版由Elsevier出版社在ScienceDirect上出版(http://www.sciencedirect.com/science/journal/18722067). 